\section{Customs delays drive researchers to smuggling}

\section{Colin Macilwain}

- ven for those fortunate scientists in

- Latin America who manage to obtain - adequate funding, have bright graduate students to work with and fast Internet links connecting them to the world of science, a major obstacle remains on the road to first-rate research: fast access to equipment and materials.

Scientists in all disciplines in most countries in the region complain about the time it takes to process major items of research equipment through customs. Often their problem is persuading every level of the customs bureaucracy that the item to be imported is duty free. Simply paying the duty is not usually an option, because funding agencies refuse to cover the cost of taxes that should not have been paid.

But it is biologists, who depend heavily on perishable reagents, including cultures, bacteria and tissue samples, who are most severely affected. Desperation often drives the region's life scientists - not to mention their colleagues at US or European universities, and even their family members on vacation - to hide materials in their luggage before making a trip south.

\section{Supplies "always late"}

The extent of the problem varies across Latin America, but its underlying effect is fairly uniform. Imported supplies are always late, and, if supplied locally, their prices are inflated to about twice US levels. Biologists learn to plan their work around the uncertain time delays. But their research institutions can make a major difference: many have specific offices dedicated to dealing with customs, and some have established offices in the United States. Institutions keep as strong an inventory of reagents as they can afford.

"You just have to plan in advance," says Igor Polikarpov, head of protein crystallography at Brazil's national synchrotron light source at Campinas. The progress that a particular reagent will make on the route through customs depends on the officer who deals with it, he says. Perishable enzymes can be destroyed by an unsympathetic inspection at customs, whereas chemicals such as acetones, which are used in cocaine processing, always attract unwanted attention.

Some other researchers in Brazil report that average delays for packages coming through customs from abroad have increased recently, after a period of improve-

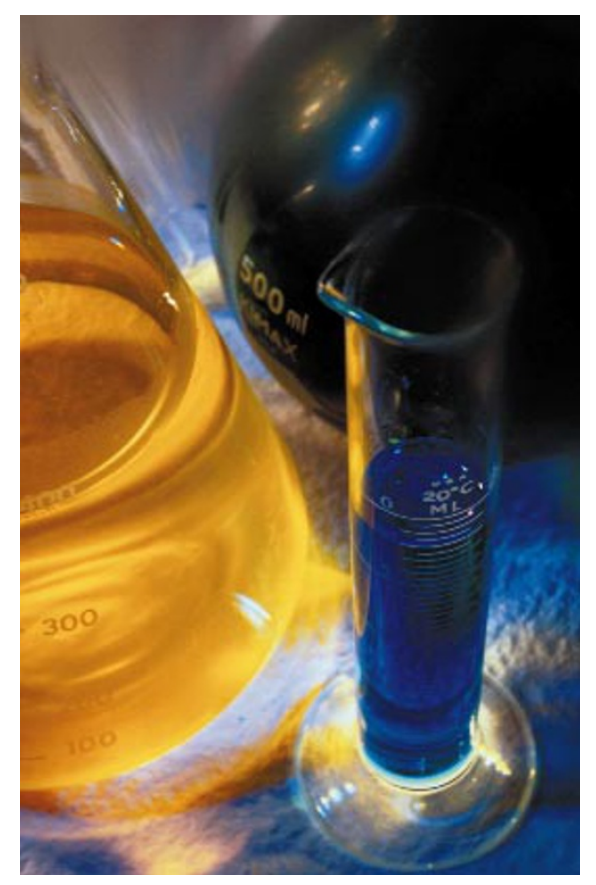

ment. "What people are doing," says one of them, "is smuggling."

Franklin Rumjanek, head of biochemistry at the Federal University of Rio de Janeiro (FURJ), says he feels defrauded by the representatives of supply companies who bring reagents into the country and charge "at least twice" the price they would charge in the United States. Rumjanek does not predict any bureaucratic solution to the problem: the only way around it, he says, is for the reagents to be produced in Brazil.

George dos Reis, a biophysicist at FURJ, says that it can take six to nine months to order some supplies, and also complains about inflated prices of locally available reagents. "It has always been like that," he says. "It's a big limitation."

In Argentina, delays reported at customs are a little less severe. "We can get items out of customs in two or three days," says Carlos Frasch, director of the Institute of Biotechnology at the University of General San Martín. "Or you can purchase it through a representative in Argentina - but that is twice the price." In all, it can take "15 or 20 days at the most" to order and receive reagents, he says.

Ordering major equipment is, however, another matter. In Argentina, securing its exemption from import duties can be a huge task. "Big pieces of equipment can take a year," says Armando Parodi of the Campo- mar Foundation in Buenos Aires, who recently waited all of 18 months for delivery of an incubator.

The two principal Chilean research universities have each established beachheads in the United States, to assist with the movement of materials. Scientists at the Catholic University often get colleagues in the United States to donate material to a company based in Miami, which then arranges fast delivery through a contract with the university.

The University of Chile, meanwhile, has established an office of its own in Washington, called University International Exchange, which although devoted chiefly to scientific exchange or collaboration, also helps some university scientists to receive donated supplies and equipment from the United States.

In Mexico, some scientists envisaged the situation improving after the country joined the North American Free Trade Association (NAFTA) in 1994. "We were all very happy about NAFTA and had high expectations," says Carlos Arias of the National Autonomous University's Institute of Biotechnology, in Cuernavaca. "But things haven't changed that much. Sometimes by the time items arrive, we forget what we wanted them for."

\section{Office at airport}

CONACYT, the Mexican research council, has an office at Mexico City airport to help expedite supplies, but some scientists are unaware of its existence. In addition to inflated prices and delays of weeks or even months for most imported reagents, Mexican scientists report particular problems obtaining chemicals whose movement is restricted by the US Drug Enforcement Agency.

Although most scientists in Latin America believe that problems with obtaining reagents are a significant hindrance, some of the more experienced ones say that these complaints are overblown. Ricardo Uauy, for example, director of the Institute of Nutrition and Food Technology (INTA) at the University of Chile, says that researchers can get what they need. Ricardo Brentani, director of the Ludwig Institute in São Paulo, bluntly rejects the assertion that materials supply is holding back Brazilian science: he suggests that some researchers use it as an excuse for bad performance.

Whatever the true extent of the problem, many different bureaucratic solutions have been proposed to deal with it. In Argentina, for example, it has been suggested that scientists simply pay duty on research materials and that customs redirects a lump sum of money back to the science agency. But scientists' best chance of alleviating the problem is to have competent, specialized staff in their institution or university to do the tiresome legwork needed to expedite materials though customs. 